\title{
Article
}

\section{The Efficient Removal of Calcium and Magnesium Ions from Industrial Manganese Sulfate Solution through the Integrated Application of Concentrated Sulfuric Acid and Ethanol}

\author{
Houyang Chen ${ }^{1,+} \oplus$, Kaituo Wang ${ }^{1,2, *,+}$, Xianquan Ming ${ }^{3}$, Feng Zhan ${ }^{3, *}$, Yaseen Muhammad ${ }^{4}(\mathbb{D}$, \\ Yuezhou Wei ${ }^{1}{ }^{1}$, Weijian $\mathrm{Li}^{3}$ and Haiqing Zhan ${ }^{3}$ \\ 1 Guangxi Key Laboratory of Processing for Non-Ferrous Metals and Featured Materials, School of Resources, \\ Environment and Materials, Guangxi University, Nanning 530004, China; chy937659953@163.com (H.C.); \\ yzwei@gxu.edu.cn (Y.W.) \\ 2 MOE Key Laboratory of New Processing Technology for Nonferrous Metals and Materials, \\ Nanning 530004, China \\ 3 South Manganese Group Co., Ltd., Nanning 530004, China; mxq@southmn.com (X.M.); \\ lwj@southmn.com (W.L.); zhq@southmn.com (H.Z.) \\ 4 Institute of Chemical Sciences, University of Peshawar, Khyber Pakhtunkhwa 25120, Pakistan; \\ myyousafzai@gmail.com \\ * Correspondence: wangkaituo@gxu.edu.cn (K.W.); phy_ideaa@outlook.com (F.Z.) \\ + These authors contributed equally to this work.
}

Citation: Chen, H.; Wang, K.; Ming, X.; Zhan, F.; Muhammad, Y.; Wei, Y.; Li, W.; Zhan, H. The Efficient Removal of Calcium and Magnesium Ions from Industrial Manganese Sulfate Solution through the Integrated Application of Concentrated Sulfuric Acid and Ethanol. Metals 2021, 11, 1339. https://doi.org/10.3390/ met11091339

Academic Editors: Jean François Blais and Srecko Stopic

Received: 17 June 2021

Accepted: 23 August 2021

Published: 25 August 2021

Publisher's Note: MDPI stays neutral with regard to jurisdictional claims in published maps and institutional affiliations.

Copyright: () 2021 by the authors. Licensee MDPI, Basel, Switzerland. This article is an open access article distributed under the terms and conditions of the Creative Commons Attribution (CC BY) license (https:// creativecommons.org/licenses/by/ $4.0 /)$.
Abstract: In the process of preparing high-purity $\mathrm{MnSO}_{4}$ from industrial $\mathrm{MnSO}_{4}$ solution, it is difficult to remove $\mathrm{Ca}^{2+}$ and $\mathrm{Mg}^{2+}$ due to their closely similar properties. In this study, thermodynamic software simulation and experimental procedures were combined to remove $\mathrm{Ca}^{2+}$ and $\mathrm{Mg}^{2+}$ from industrial $\mathrm{MnSO}_{4}$ solution to obtain high-purity $\mathrm{MnSO}_{4}$. The simulation model was applied to predict the trend of the crystallization of different ions in the solution upon the addition of $\mathrm{H}_{2} \mathrm{SO}_{4}$, which revealed that, at a volume ratio of $\mathrm{H}_{2} \mathrm{SO}_{4}$ to $\mathrm{MnSO}_{4}$ solution of more than $0.2, \mathrm{MnSO}_{4}$ started to crystallize and precipitate. The experimental results further verified the simulation results, and the yield of $\mathrm{MnSO}_{4}$ increased with the increasing ratio of $\mathrm{H}_{2} \mathrm{SO}_{4}$, while the removal rate of $\mathrm{Ca}^{2+}$ and $\mathrm{Mg}^{2+}$ decreased gradually. Keeping the economic aspect in mind, the 0.3 ratio of $\mathrm{H}_{2} \mathrm{SO}_{4}$ was selected at which the yield of $\mathrm{MnSO}_{4}$ reached $86.44 \%$. The removal rate of $\mathrm{Ca}^{2+}$ and $\mathrm{Mg}^{2+}$ by recrystallization reached $99.68 \%$ and $99.17 \%$ respectively after six consecutive cycles. The recrystallized sample was washed twice with anhydrous ethanol (volume ratio of ethanol to $\mathrm{MnSO}_{4}$ solution of 0.5 ) and dried for $6 \mathrm{~h}$ at $120^{\circ} \mathrm{C}$, and the purity of $\mathrm{MnSO}_{4} \cdot \mathrm{H}_{2} \mathrm{O}$ reached the battery grade requirements with the final yield as high as $80.54 \%$. This study provides important guideline information for the purification of $\mathrm{MnSO}_{4} \cdot \mathrm{H}_{2} \mathrm{O}$ from industrial $\mathrm{MnSO}_{4}$ solution via a cost-effective, simple and facile approach.

Keywords: OLI Stream Analyzer; high-purity $\mathrm{MnSO}_{4}$; recrystallization; $\mathrm{Ca}^{2+}$ and $\mathrm{Mg}^{2+}$ removal

\section{Introduction}

$\mathrm{MnSO}_{4}$, as a base manganese salt, is used in the preparation of various advanced manganese-based alloys and products [1-4]. The front drive system of the positive triumvirate of a battery's material (Ni-Cobalt Manganese Acid Lithium) requires high-purity $\mathrm{MnSO}_{4}$, where the major impurities include potassium, sodium, calcium and magnesium (the sum of the concentration of calcium and magnesium impurities is $\leq 0.05 \%$ ) $[5,6]$. In order to obtain these high-quality manganese-based materials for use in batteries, the purity of manganese-based raw materials must be solved first. Therefore, the deep decontamination of $\mathrm{MnSO}_{4}$ solution for producing high-grade materials to be used in lithium-ion batteries has become a research hotspot [7].

Among the many impurities like $\mathrm{K}^{+}, \mathrm{Na}^{+}, \mathrm{Ca}^{2+}$ and $\mathrm{Mg}^{2+}$, the chemical properties of manganese are closely similar to the calcium and magnesium present in $\mathrm{MnSO}_{4}$ solu- 
tion, and hence it becomes very tough to prepare $\mathrm{MnSO}_{4}$ for meeting the requirements of high-purity $\mathrm{MnSO}_{4}$ via traditional decontamination methods [8,9]. In addition, $\mathrm{Ca}^{2+}$ and $\mathrm{Mg}^{2+}$ have a great impact on many subsequent processes, and in the electrolytic manganese phase, they affect the current efficiency of electrolysis and the purity of electrolytic manganese products. The traditional methods for the removal of $\mathrm{Ca}^{2+}$ and $\mathrm{Mg}^{2+}$ in $\mathrm{MnSO}_{4}$ solution mainly include chemical precipitation [10,11], recrystallization [12,13], fluoridation [14], extraction [15-17], and electrolysis [18]. Recrystallization includes evaporative concentration, high temperature and pressure crystallization [19-21], where it uses $\mathrm{MnSO}_{4}$ solubility, which shows a sharp decrease at temperatures of over $100{ }^{\circ} \mathrm{C}$, and the $\mathrm{MnSO}_{4}$ crystals are obtained by heating the solution in the high-pressure reactor. This process is very stringent on the material and quality requirements of the equipment, otherwise it can affect the normal safe operation of the system [22,23]. The fluoride method uses the difference between the solubilities between manganese fluoride, calcium fluoride and magnesium fluoride, and the decontamination of $\mathrm{Ca}^{2+}$ and $\mathrm{Mg}^{2+}$ [24]. However, this method introduces $\mathrm{Na}^{+}, \mathrm{NH}_{4}{ }^{+}$and $\mathrm{F}^{-}$as impurities while removing $\mathrm{Ca}^{2+}$ and $\mathrm{Mg}^{2+}$, and high-purity $\mathrm{MnSO}_{4}$ needs to be treated with extractors and adsorbents for their removal. In addition, the waste liquid and residue produced by this process contains hazardous $\mathrm{F}^{-}$ which requires further purification processes. The extraction method utilizes the difference in solubilities of $\mathrm{Mn}^{2+}$ and the impurity ions $\left(\mathrm{K}^{+}, \mathrm{Na}^{+}, \mathrm{Ca}^{2+}\right.$ and $\left.\mathrm{Mg}^{2+}\right)$ in different extractants for effective separation [25], but the product purity and recovery rate obtained by this method is low. Electrolysis uses the difference in the rate of precipitation of manganese ions and impurity ions in manganese sulfate leaching solution, though it generates hydrogen, which poses a safety hazard.

In view of the aforementioned shortcomings of traditional $\mathrm{MnSO}_{4}$ purification processes, and to maintain the sustainable exploitation of resources and the perspective of economic development, it is particularly important to study, develop and apply new processes for the generation of high-purity $\mathrm{MnSO}_{4}$. Thus, this study applies the approach of variation in the solubility-product constant $\left(\mathrm{K}_{\mathrm{sp}}\right)$ of $\mathrm{Mn}^{2+}$, and $\mathrm{Ca}^{2+}$ and $\mathrm{Mg}^{2+}$ in the water$\mathrm{H}_{2} \mathrm{SO}_{4}$ system for the preparation of high-purity $\mathrm{MnSO}_{4} \cdot \mathrm{H}_{2} \mathrm{O}$ at room temperature $[26,27]$. The impurity ions are removed by repeated recrystallization, and the $\mathrm{H}_{2} \mathrm{SO}_{4}$ remaining on the surface is washed with ethanol, with the high-purity $\mathrm{MnSO}_{4} \cdot \mathrm{H}_{2} \mathrm{O}$ obtained after drying. Compared with the traditional synthesis method, this method is cost- and energy-effective and simplified with reduced mechanical requirements, while maintaining sustainable and green development approaches by effectively utilizing waste and environmentally friendly materials for the production of high-purity $\mathrm{MnSO}_{4} \cdot \mathrm{H}_{2} \mathrm{O}$.

\section{Experimental Section}

\subsection{Materials and Equipment}

The concentration of various ions in the $\mathrm{MnSO}_{4}$ leaching solution (CITIC Dameng Mining Industries Limited Chongzuo Branch, Nanning, Guangxi, China) used in this work is shown in Table $1(\mathrm{pH}=2.8)$. The $\mathrm{H}_{2} \mathrm{SO}_{4}$ used in this experiment was obtained from Chengdu Kelong chemical reagent factory, China. Ethanol was provided by Guangdong Guanghua Sci-Tech Co., Ltd., Guangzhou China. The constant-temperature magnetic heating mixer was provided by Gongyi Yuhua Instrument Co., Ltd. Ethanol was recovered via a rotary evaporator (EYELA-1300D-WB, Tokyo Japan), while solution pH was tested via a $\mathrm{pH}$ meter provided by Shanghai San-Xin Instrumentation, China.

Table 1. The concentration of ions in the $\mathrm{MnSO}_{4}$ leaching solution $(\mathrm{g} / \mathrm{L})$.

\begin{tabular}{|c|c|c|c|c|c|c|c|c|}
\hline Ion & $\operatorname{Mn}(g / L)$ & $\mathrm{Mg}(\mathrm{mg} / \mathrm{L})$ & $\mathrm{Ca}(\mathrm{mg} / \mathrm{L})$ & $\mathrm{Na}(\mathrm{mg} / \mathrm{L})$ & $\mathrm{K}(\mathrm{mg} / \mathrm{L})$ & $\mathrm{Ni}(\mathrm{mg} / \mathrm{L})$ & Co $(\mathrm{mg} / \mathrm{L})$ & $\mathrm{Zn}(\mathrm{mg} / \mathrm{L})$ \\
\hline Concentration & 139.20 & 1726.39 & 544.95 & 93.11 & 23.62 & 236.87 & 64.20 & 48.20 \\
\hline & \pm 1.24 & \pm 39.51 & \pm 8.99 & \pm 9.13 & \pm 6.91 & \pm 6.88 & \pm 1.02 & \pm 7.94 \\
\hline
\end{tabular}




\subsection{Simulation Software and Methods}

OLI Stream Analyzer predicted the system phase equilibrium and crystallization thermodynamic process of complex chemical mixtures in aqueous systems. Different $\mathrm{pH}$ values, temperature and pressure could be adjusted according to experimental requirements, and the solute saturation point, precipitation point, acid-base titration curve and thermodynamic properties of the components and their dependence relationships could be simulated and predicted. The ratio of $\mathrm{H}_{2} \mathrm{SO}_{4}$ to the crystallization trend of different components and the change of $\mathrm{MnSO}_{4} \cdot \mathrm{H}_{2} \mathrm{O}$ yield with temperature were calculated by the software OLI Stream Analyzer version 3.1.

\subsection{Preparation of High-Purity $\mathrm{MnSO}_{4} \cdot \mathrm{H}_{2} \mathrm{O}$}

High-purity $\mathrm{MnSO}_{4} \cdot \mathrm{H}_{2} \mathrm{O}$ was prepared by $\mathrm{H}_{2} \mathrm{SO}_{4}$ in coordination with ethanol, and this preparation process is shown in Figure 1. Firstly, $50 \mathrm{~mL}$ of $\mathrm{MnSO}_{4}$ solution was taken in a beaker at room temperature, and $15 \mathrm{~mL}$ of $\mathrm{H}_{2} \mathrm{SO}_{4}$ was slowly added to it under continuous stirring. When the crystals were completely precipitated, stirring was stopped and the crystals were separated from the solution. The obtained crystals were re-dissolved with $30 \mathrm{~mL}$ deionized water, and then $15 \mathrm{~mL} \mathrm{H}_{2} \mathrm{SO}_{4}$ was slowly added to completely precipitate the crystals. This process was repeated 6 times. Secondly, the filtered $\mathrm{MnSO}_{4}$ crystals were washed with $50 \mathrm{~mL}$ of ethanol in two steps to remove $\mathrm{H}_{2} \mathrm{SO}_{4}$ on the surface, and ethanol was recycled through the rotary evaporator. Finally, the $\mathrm{MnSO}_{4}$ crystals were dried at $120^{\circ} \mathrm{C}$ for $6 \mathrm{~h}$ to obtain high-purity $\mathrm{MnSO}_{4} \cdot \mathrm{H}_{2} \mathrm{O}$.

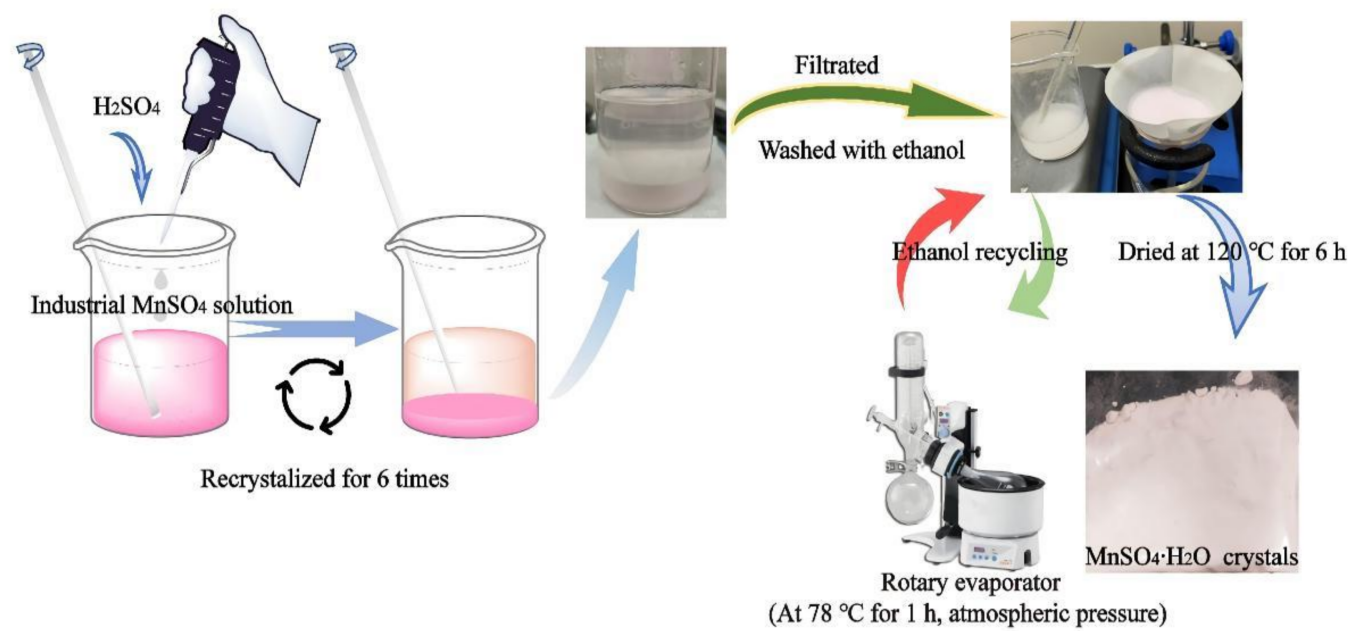

Figure 1. Preparation flow chart of $\mathrm{MnSO}_{4} \cdot \mathrm{H}_{2} \mathrm{O}$ crystals.

\subsection{Characterization}

X-ray powder diffraction (XRD, Rigaku MiniFlex 600, Japan) was used to analyze the crystal phase structure of $\mathrm{MnSO}_{4} \cdot \mathrm{H}_{2} \mathrm{O}$ in scanning range of $10-70^{\circ}(2 \theta)$ at a rate of $5^{\circ} / \mathrm{min}$ under Fe- $\mathrm{K} \alpha$ as anode target, $40 \mathrm{kV}$ and $15 \mathrm{~mA}$ conditions. The sample was digested with $5 \% \mathrm{HCl}$. The concentrations of various metal ions in manganese sulphate leaching solution and filtrate were measured by inductively coupled plasma atomic emission spectroscopy (ICPS-7510, Shimadzu, Japan) and atomic absorption spectrophotometer (AA-7000, Shimadzu, Japan), respectively.

\section{Results and Discussions}

\subsection{Simulation Results of OLI Stream Analyzer Software}

The density of the industrial $\mathrm{MnSO}_{4}$ solution used in this experiment was $1.3127 \pm 0.0004 \mathrm{~g} / \mathrm{cm}^{3}$, and the density calculated by the OLI Stream Analyzer software was $1.2982 \mathrm{~g} / \mathrm{cm}^{3}$, hence it could be concluded that the OLI Stream Analyzer software could be used to simulate and calculate the industrial $\mathrm{MnSO}_{4}$ solution. The software was used to calculate the scaling trend and yield changes of different components of industrial 
$\mathrm{MnSO}_{4}$ solution with the addition ratio of $\mathrm{H}_{2} \mathrm{SO}_{4}$. As shown in Figure $2 \mathrm{~A}$, the scaling trend of $\mathrm{MnSO}_{4} \cdot \mathrm{H}_{2} \mathrm{O}, \mathrm{CaSO}_{4}$ and $\mathrm{MgSO}_{4} \cdot \mathrm{H}_{2} \mathrm{O}$ increased with the increasing ratio of $\mathrm{H}_{2} \mathrm{SO}_{4}$. When the ratio of $\mathrm{H}_{2} \mathrm{SO}_{4}$ reached $6 \%$ and $10 \%$, the scaling trend of $\mathrm{MnSO}_{4} \cdot \mathrm{H}_{2} \mathrm{O}$ and $\mathrm{CaSO}_{4}$ in the solution reached 1 [28], which indicated that $\mathrm{MnSO}_{4} \cdot \mathrm{H}_{2} \mathrm{O}$ and $\mathrm{CaSO}_{4}$ were saturated and had reached the precipitation condition. In contrast, the $\mathrm{MgSO}_{4} \cdot \mathrm{H}_{2} \mathrm{O}$ crystal does not match the precipitation condition. In a temperature range of $25-85^{\circ} \mathrm{C}$, the change trend of $\mathrm{MnSO}_{4} \cdot \mathrm{H}_{2} \mathrm{O}$ yield with the ratio of $\mathrm{H}_{2} \mathrm{SO}_{4}$ is shown in Figure $2 \mathrm{~B}$. The yield of $\mathrm{MnSO}_{4} \cdot \mathrm{H}_{2} \mathrm{O}$ increased with the increasing ratio of $\mathrm{H}_{2} \mathrm{SO}_{4}$, and was sensitive to temperature change when the ratio of $\mathrm{H}_{2} \mathrm{SO}_{4}$ was less than $26 \%$, the main reason for this was that the solubility of manganese sulfate decreased with the increase of temperature at $25-85^{\circ} \mathrm{C}$, which led to the increase of crystallization yield. However, when the $\mathrm{H}_{2} \mathrm{SO}_{4}$ concentration was high and the ratio exceeded $26 \%$, the $\mathrm{MnSO}_{4} \cdot \mathrm{H}_{2} \mathrm{O}$ saturation increased. Under the condition of a ratio of $30 \% \mathrm{H}_{2} \mathrm{SO}_{4}$, the solution degree of $\mathrm{MnSO}_{4} \cdot \mathrm{H}_{2} \mathrm{O}$, increased with the increase in temperature, which led to a slight change in the crystallization yield. Therefore, when the ratio of $\mathrm{H}_{2} \mathrm{SO}_{4}$ was $30 \%$, the maximum yield of $\mathrm{MnSO}_{4} \cdot \mathrm{H}_{2} \mathrm{O}$ was $82.2 \%$ at $25{ }^{\circ} \mathrm{C}$.
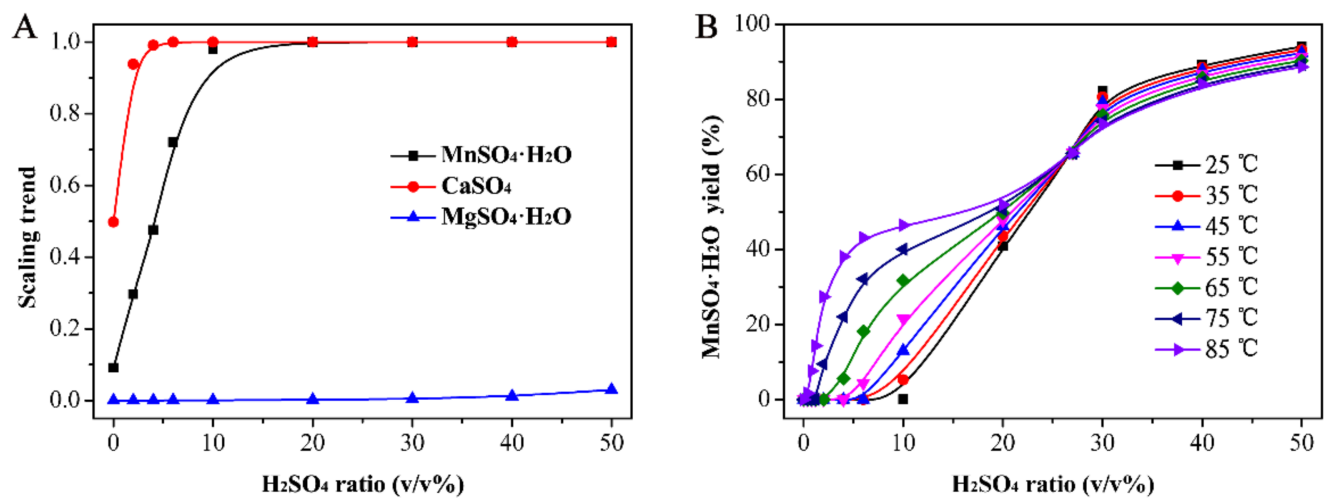

Figure 2. The scaling trend (A) of different components of industrial $\mathrm{MnSO}_{4}$ solution with the addition ratio of $\mathrm{H}_{2} \mathrm{SO}_{4}$ and $\mathrm{MnSO}_{4} \cdot \mathrm{H}_{2} \mathrm{O}$ yield (B) in the temperature range of $25-85{ }^{\circ} \mathrm{C}$.

\subsection{Calculated and Tested Yield of Different Components}

Under the condition of $25^{\circ} \mathrm{C}$, in order to obtain the influence of $\mathrm{H}_{2} \mathrm{SO}_{4}$ on the yield of different components $\left(\mathrm{MnSO}_{4} \cdot \mathrm{H}_{2} \mathrm{O}, \mathrm{CaSO}_{4}\right.$ and $\left.\mathrm{MgSO}_{4} \cdot \mathrm{H}_{2} \mathrm{O}\right)$, the comparison of the results of the calculations and tests were used to obtain the yield of different components of industrial $\mathrm{MnSO}_{4}$ solution, with the addition of $\mathrm{H}_{2} \mathrm{SO}_{4}$ in different ratios. As shown in Figure 3, the calculated and tested yield of $\mathrm{MnSO}_{4} \cdot \mathrm{H}_{2} \mathrm{O}$ was very close to the change trend of the ratio of $\mathrm{H}_{2} \mathrm{SO}_{4}$ and increased proportionally with increasing $\mathrm{H}_{2} \mathrm{SO}_{4}$ ratio. When the ratio of $\mathrm{H}_{2} \mathrm{SO}_{4}$ exceeded $30 \%$, its increasing trend was not obvious. The calculated and tested yields were $82.2 \%$ and $86.6 \%$, respectively, at a $30 \% \mathrm{H}_{2} \mathrm{SO}_{4}$ ratio. As the ratio of $\mathrm{H}_{2} \mathrm{SO}_{4}$ increased, a wide gap appeared between the calculated and tested yield of $\mathrm{CaSO}_{4}$, which was mainly because the industrial $\mathrm{MnSO}_{4}$ solution was laden with a high content of salt (the content of $\mathrm{MnSO}_{4}$ exceeds $100 \mathrm{~g} / \mathrm{L}$ ) and the force between the ions was strengthened, which increases the solubility of $\mathrm{CaSO}_{4}$ [19]. Hence, the actual amount of $\mathrm{CaSO}_{4}$ precipitation was minimal, which was beneficial for the removal of $\mathrm{Ca}^{2+} \cdot \mathrm{MgSO}_{4} \cdot \mathrm{H}_{2} \mathrm{O}$ precipitation was not generated in the simulation calculation, but $\mathrm{MgSO}_{4} \cdot \mathrm{H}_{2} \mathrm{O}$ crystals were found in the actual test. This was because $\mathrm{MnSO}_{4}$ and $\mathrm{MgSO}_{4}$ in the solution were similar in structure and could form a mixed crystal system [29]. $\mathrm{MgSO}_{4}$ could attach to the solid surface of $\mathrm{MnSO}_{4} \cdot \mathrm{H}_{2} \mathrm{O}$ for the heterogeneous nucleation and in the actual crystallization process. 


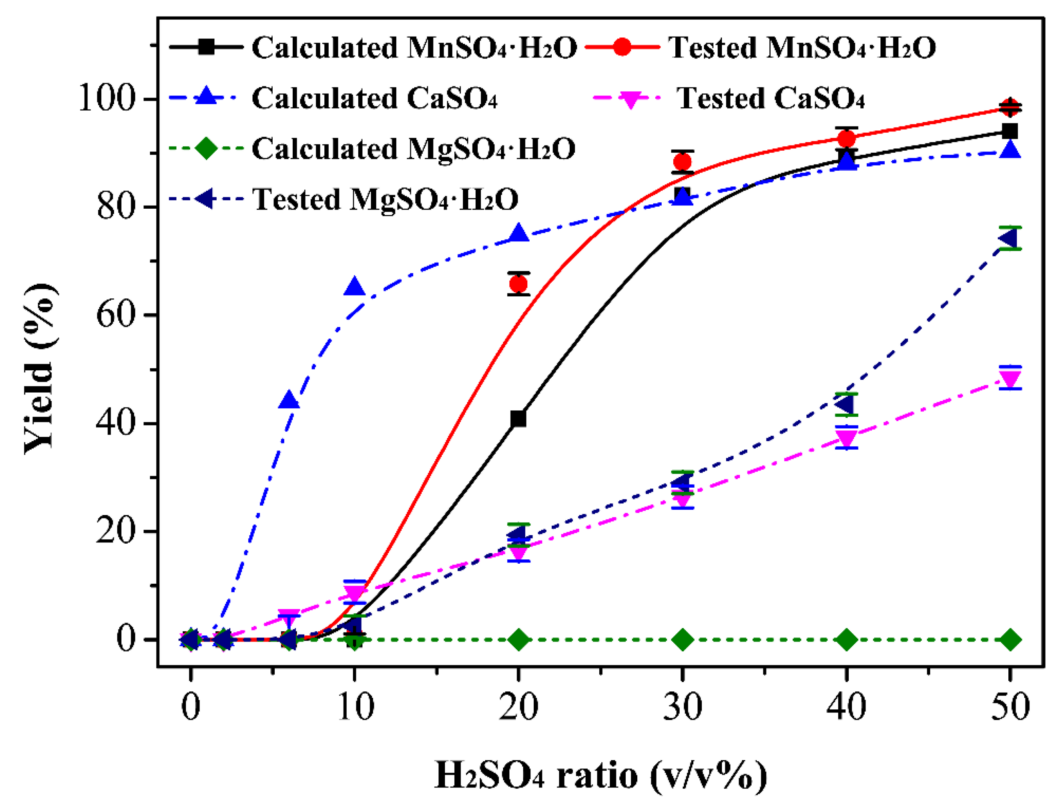

Figure 3. The calculated and tested yield of different components of industrial $\mathrm{MnSO}_{4}$ solution with the addition ratio of $\mathrm{H}_{2} \mathrm{SO}_{4}$.

\subsection{Determination of the Optimal Ratio of $\mathrm{H}_{2} \mathrm{SO}_{4}$}

The change trend of the $\mathrm{MnSO}_{4} \cdot \mathrm{H}_{2} \mathrm{O}$ yield and $\mathrm{Ca}^{2+}, \mathrm{Mg}^{2+}$ removal rate with the ratio of $\mathrm{H}_{2} \mathrm{SO}_{4}$ was explored in a range from $20-50 \%$. As shown in Figure 4, the yield of $\mathrm{MnSO}_{4} \cdot \mathrm{H}_{2} \mathrm{O}$ increased with increasing the ratio of $\mathrm{H}_{2} \mathrm{SO}_{4}$, while the change in the removal rate of $\mathrm{Ca}^{2+}$ and $\mathrm{Mg}^{2+}$ demonstrated the opposite trend. Considering the actual production cost and the results of the previous calculations, the optimal ratio of $\mathrm{H}_{2} \mathrm{SO}_{4}$ was determined to be $30 \%$ and at this ratio, the $\mathrm{MnSO}_{4} \cdot \mathrm{H}_{2} \mathrm{O}$ crystal yield was $86.60 \%$, and the removal rates of $\mathrm{Ca}^{2+}$ and $\mathrm{Mg}^{2+}$ were $65.25 \%$ and $70.91 \%$, respectively.

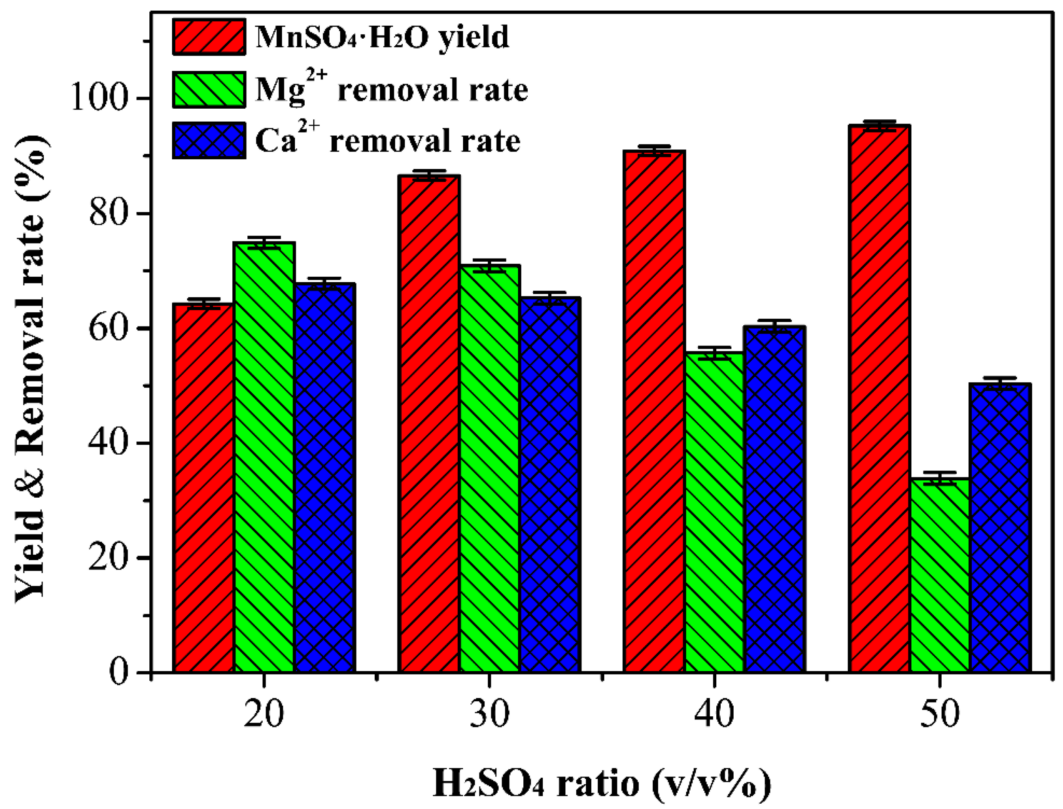

Figure 4. The effect of $\mathrm{H}_{2} \mathrm{SO}_{4}$ ratio on $\mathrm{MnSO}_{4} \cdot \mathrm{H}_{2} \mathrm{O}$ yield and $\mathrm{Mg}^{2+}, \mathrm{Ca}^{2+}$ removal rate.

\subsection{Recrystallization Experiment}

In order to obtain high-purity $\mathrm{MnSO}_{4} \cdot \mathrm{H}_{2} \mathrm{O}$ crystals, it was necessary to perform recrystallization experiments on the obtained $\mathrm{MnSO}_{4} \cdot \mathrm{H}_{2} \mathrm{O}$. The ratio of $\mathrm{H}_{2} \mathrm{O}$ and the 
number of cycles in the recrystallization process had a great influence on the yield of $\mathrm{MnSO}_{4} \cdot \mathrm{H}_{2} \mathrm{O}$ and the removal rates of $\mathrm{Ca}^{2+}$ and $\mathrm{Mg}^{2+}[30]$. The solubility of $\mathrm{MnSO}_{4}$ at $25^{\circ} \mathrm{C}$ was around $64.8 \mathrm{~g} / 100 \mathrm{~g} \mathrm{H}_{2} \mathrm{O}$ [31], and hence the ratio of $\mathrm{H}_{2} \mathrm{O}$ added (the volume ratio of $\mathrm{H}_{2} \mathrm{O}$ to the original $\mathrm{MnSO}_{4}$ solution) varied between $60-100 \%$. As shown in Figure $5 \mathrm{~A}$, the yield of $\mathrm{MnSO}_{4} \cdot \mathrm{H}_{2} \mathrm{O}$ decreased with an increase in the ratio of $\mathrm{H}_{2} \mathrm{O}$ which was because the dissolution loss of $\mathrm{MnSO}_{4}$ increased as the amount of water increased, and finally determined that $60 \%$ was the optimum ratio of $\mathrm{H}_{2} \mathrm{O}$. It can be seen from Figure $5 \mathrm{~B}$ that the yield of $\mathrm{MnSO}_{4} \cdot \mathrm{H}_{2} \mathrm{O}$ decreased with the increase of the number of cycles, while the removal rate of $\mathrm{Ca}^{2+}$ and $\mathrm{Mg}^{2+}$ gradually increased. However, the yield of $\mathrm{MnSO}_{4} \cdot \mathrm{H}_{2} \mathrm{O}$ changed marginally, and still reached $80.54 \%$ after six cycles. The residual content (wt.\%) of $\mathrm{Mg}^{2+}$ and $\mathrm{Ca}^{2+}$ in $\mathrm{MgSO}_{4} \cdot \mathrm{H}_{2} \mathrm{O}$ with different recrystallization cycles in Table 2 suggested that $\mathrm{Ca}^{2+}$ content attained the requirement $(\leq 0.0050 \%)$ after two cycles while $\mathrm{Mg}^{2+}$ needed six cycles to attain this requirement. The preparation of high-purity $\mathrm{MnSO}_{4} \cdot \mathrm{H}_{2} \mathrm{O}$ crystals in this paper required a minimum of six cycles. During the experiment, excessive concentrated $\mathrm{H}_{2} \mathrm{SO}_{4}$ was recovered and used in industry to prepare $\mathrm{MnSO}_{4}$ solution by leaching manganese ore. Therefore, the recycling of $\mathrm{H}_{2} \mathrm{SO}_{4}$ could effectively save immeasurable production costs. At present, compared with the traditional extraction method, this technology was not only simple in operation, lower in cost, and larger in production scale, but also through preliminary feasibility analysis, the annual economic benefits of using this technology were at least twice that of the traditional technology.
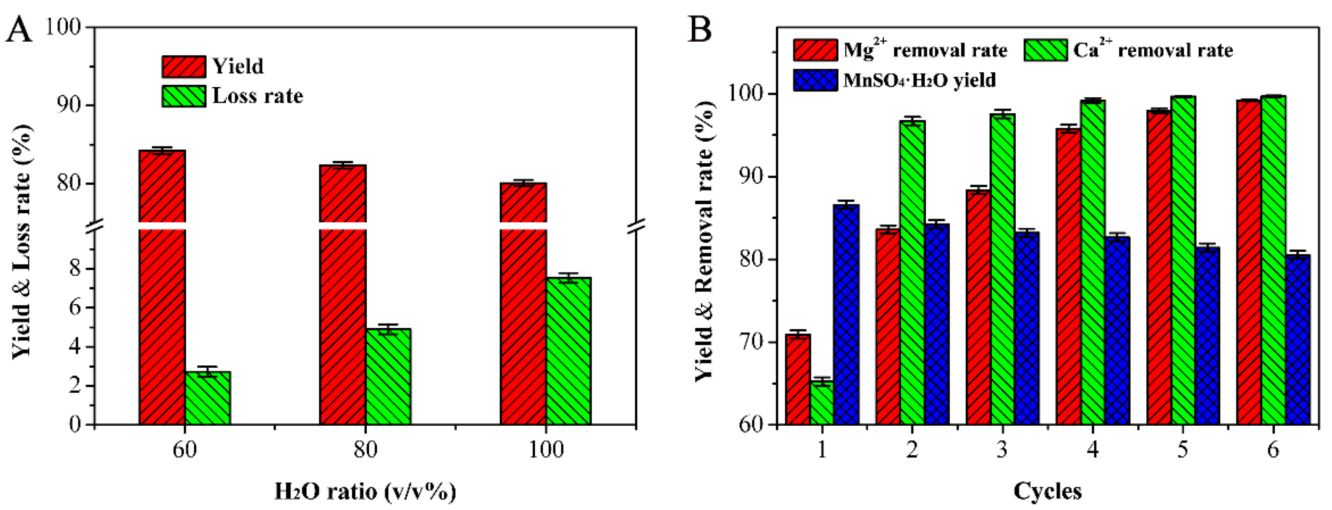

Figure 5. (A) The effect of $\mathrm{H}_{2} \mathrm{O}$ ratio on $\mathrm{MnSO}_{4} \bullet \mathrm{H}_{2} \mathrm{O}$ yield during recrystallization; (B) The effect of cycles on $\mathrm{MnSO}_{4} \bullet \mathrm{H}_{2} \mathrm{O}$ yield and $\mathrm{Mg}^{2+}, \mathrm{Ca}^{2+}$ removal rate.

Table 2. Residual content (wt.\%) of $\mathrm{Mg}^{2+}$ and $\mathrm{Ca}^{2+}$ in $\mathrm{MnSO}_{4} \bullet \mathrm{H}_{2} \mathrm{O}$ with different recrystallization cycles.

\begin{tabular}{ccc}
\hline Cycle Number & Mg/wt.\% & Ca/wt. $\%$ \\
\hline 1 & 0.11 & 0.042 \\
2 & 0.062 & 0.0040 \\
3 & 0.044 & 0.0030 \\
4 & 0.016 & 0.0010 \\
5 & 0.0078 & 0.00044 \\
6 & 0.0031 & 0.00039 \\
\hline
\end{tabular}

\subsection{Determination of the Optimal Ratio of Ethanol}

The final product obtained in this study were high-purity $\mathrm{MnSO}_{4} \cdot \mathrm{H}_{2} \mathrm{O}$ crystals, which needed to be dried. Figure $6 \mathrm{~A}$ shows that when the filtered sample was dried at $120^{\circ} \mathrm{C}$ for $6 \mathrm{~h}$, the whole sample was still stuck together and there was lot of water on the surface. This was mainly because the system contained a large amount of $\mathrm{H}_{2} \mathrm{SO}_{4}$ covering the surface of the filtered sample, while its strong water absorption properties made it difficult to remove the water from the sample. The study found that the solubility of $\mathrm{MnSO}_{4} \cdot \mathrm{H}_{2} \mathrm{O}$ 
in ethanol was very small [32]. Therefore, ethanol was used to clean the $\mathrm{H}_{2} \mathrm{SO}_{4}$ covering the surface of the sample to obtain a dry sample, and part of the $\mathrm{MgSO}_{4}$ impurity could be removed during the washing process. It can be seen from Figure $6 \mathrm{~B}-\mathrm{F}$ that the sample gradually became loose and dry as the ratio of ethanol increased (the volume ratio of ethanol to the original $\mathrm{MnSO}_{4}$ solution). The sample gradually became loose and dry, and at $100 \%$ volume ratio of ethanol, loose and dry $\mathrm{MnSO}_{4} \cdot \mathrm{H}_{2} \mathrm{O}$ crystals were obtained. Figure 7A shows that the yield of $\mathrm{MnSO}_{4} \cdot \mathrm{H}_{2} \mathrm{O}$ crystals gradually decreased as the ratio of ethanol increased, which was because the increase in the ratio of ethanol led to an increase in dissolved $\mathrm{MnSO}_{4}$ [33]. In addition, the $\mathrm{MnSO}_{4}$ samples obtained with different ethanol ratios were placed in a laboratory environment, and the water absorption rate was explored to confirm the complete removal of $\mathrm{H}_{2} \mathrm{SO}_{4}$. As shown in Figure $7 \mathrm{~B}$, the water absorption rate of $\mathrm{MnSO}_{4}$ samples obtained with different ethanol ratios increased with time while that of $\mathrm{MnSO}_{4} \cdot \mathrm{H}_{2} \mathrm{O}$ crystals changed little with time at an ethanol ratio of $100 \%$ and $120 \%$, respectively which proved that $\mathrm{H}_{2} \mathrm{SO}_{4}$ had been successfully removed. From these experiments, a $100 \%$ ethanol ratio was selected as the optimum value.

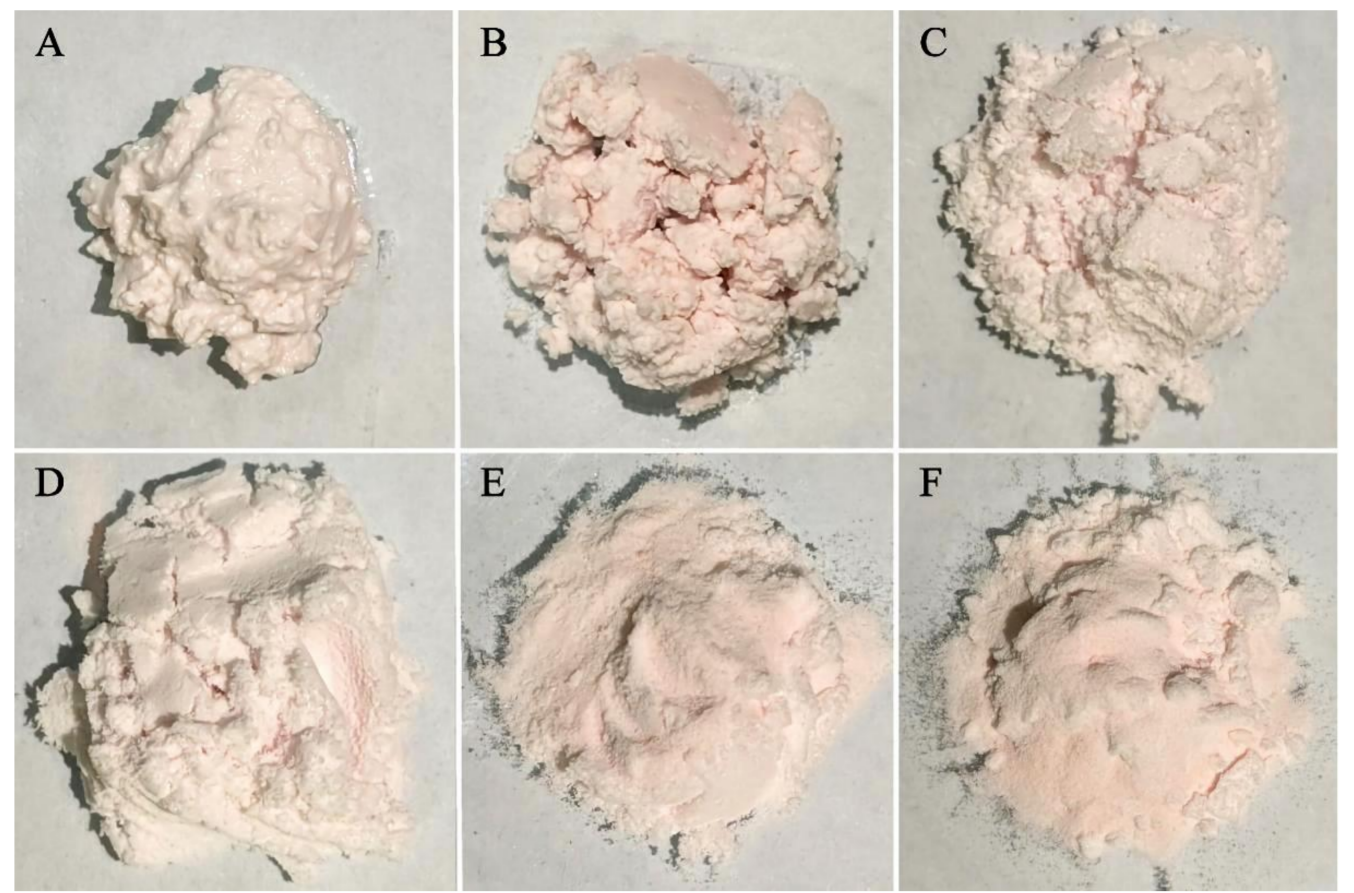

Figure 6. Sample photos of $\mathrm{MnSO}_{4} \bullet \mathrm{H}_{2} \mathrm{O}$ after washing with different ethanol ratios: $0 \%$ (A), $40 \%$ (B), $60 \%(C), 80 \%(D), 100 \%(E)$ and $120 \%(F)$, and drying at $120{ }^{\circ} \mathrm{C}$ for $6 \mathrm{~h}$.
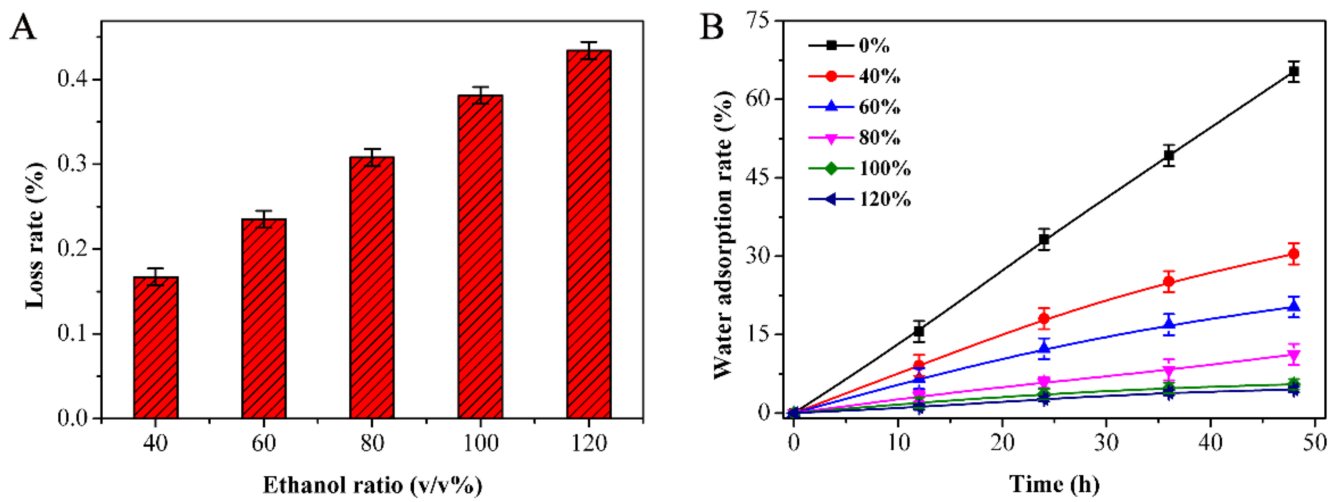

Figure 7. The effect of different ethanol ratios on the loss rate of $\mathrm{MnSO}_{4} \bullet \mathrm{H}_{2} \mathrm{O}$ (A) and the water absorption rate of $\mathrm{MnSO}_{4}(\mathbf{B})$. 


\subsection{High-Purity $\mathrm{MnSO}_{4} \cdot \mathrm{H}_{2} \mathrm{O}$ Test Results}

The $\mathrm{MnSO}_{4} \cdot \mathrm{H}_{2} \mathrm{O}$ prepared in this study was tested with reference to the HG/T48232015 Manganese sulfate for battery materials; the ICP and AAS test results are shown in Table 3. It can be seen that the contents of all of the residual impurity ions had reached the test standards, especially those of $\mathrm{Ca}^{2+}$ and $\mathrm{Mg}^{2}$ which were $0.002 \mathrm{wt} \%$ and $0.004 \mathrm{wt} \%$, respectively, much lower than the test standards. In addition, the $\mathrm{pH}$ of the final product at $\left(100 \mathrm{~g} / \mathrm{L}, 25^{\circ} \mathrm{C}\right)$ was 4.0 , which was within the range of the standards (4.0-6.5) [4]. Furthermore, the experimental sample and commercial high-purity $\mathrm{MnSO}_{4} \cdot \mathrm{H}_{2} \mathrm{O}$ crystals $(99.99 \%)$ were analyzed by XRD. Figure 8 shows that the peak shapes of the two crystals were the same and consistent with the standard card (PDF\# 81-0018 $\mathrm{MnSO}_{4} \cdot \mathrm{H}_{2} \mathrm{O}$ ), which further proved that the prepared product consisted of high-purity $\mathrm{MnSO}_{4} \cdot \mathrm{H}_{2} \mathrm{O}$ crystals.

Table 3. Test standards and ICP/AAS results of high-purity $\mathrm{MnSO}_{4} \bullet \mathrm{H}_{2} \mathrm{O}$ crystals.

\begin{tabular}{ccc}
\hline \multirow{2}{*}{ Inspected Item } & & Wt. $\%$ \\
\cline { 2 - 3 } & Standard & Result \\
\hline $\mathrm{MnSO}_{4} \cdot \mathrm{H}_{2} \mathrm{O}$ & $\geq 99$ & 99.3 \\
$\mathrm{Mn}$ & $\geq 32$ & 32.3 \\
$\mathrm{Fe}$ & $\leq 0.001$ & 0.0005 \\
$\mathrm{Zn}$ & $\leq 0.001$ & 0.004 \\
$\mathrm{Cu}$ & $\leq 0.001$ & $<0.001$ \\
$\mathrm{~Pb}$ & $\leq 0.001$ & 0.0005 \\
$\mathrm{Cd}$ & $\leq 0.0005$ & 0.0001 \\
$\mathrm{~K}$ & $\leq 0.01$ & $<0.001$ \\
$\mathrm{Na}$ & $\leq 0.01$ & 0.002 \\
$\mathrm{Ca}$ & $\leq 0.01$ & 0.002 \\
$\mathrm{Mg}$ & $\leq 0.01$ & 0.004 \\
$\mathrm{Ni}$ & $\leq 0.005$ & $<0.001$ \\
$\mathrm{Co}$ & $\leq 0.005$ & 0.001 \\
insoluble residue & $\leq 0.01$ & 0.007 \\
$\mathrm{pH}\left(100 \mathrm{~g} / \mathrm{L}, 2{ }^{\circ} \mathrm{C}\right)$ & $4.0-6.5$ & 4.0 \\
\hline
\end{tabular}

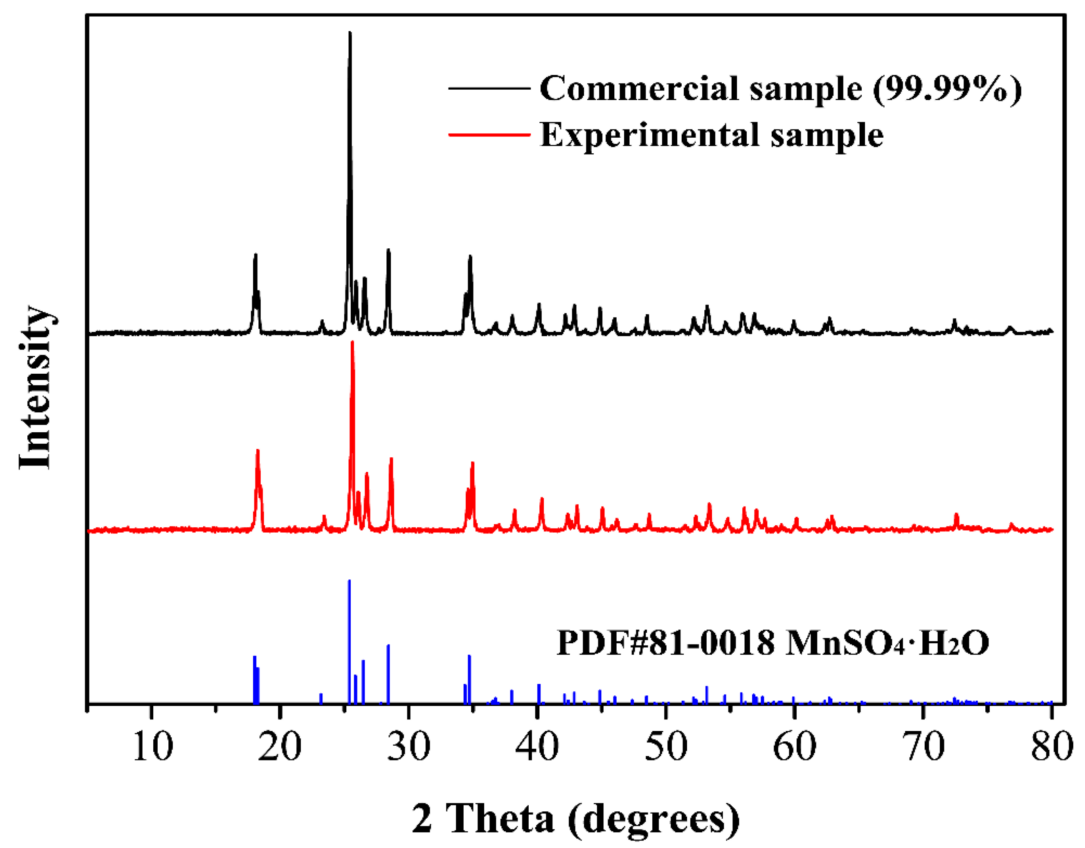

Figure 8. XRD comparison between $\mathrm{MnSO}_{4} \bullet \bullet \mathrm{H}_{2} \mathrm{O}$ crystals obtained in the experiment and commercial high-purity $\mathrm{MnSO}_{4} \bullet \mathrm{H}_{2} \mathrm{O}$ crystals. 


\section{Conclusions}

In this study, the OLI Stream Analyzer software was used to calculate the scaling trend of the industrial $\mathrm{MnSO}_{4}$ solution and the $\mathrm{MnSO}_{4} \cdot \mathrm{H}_{2} \mathrm{O}$ yield at different temperatures with the ratio of $\mathrm{H}_{2} \mathrm{SO}_{4}$. The scaling trend revealed the reason why $\mathrm{Ca}^{2+}$ and $\mathrm{Mg}^{2+}$ could be separated. According to the $\mathrm{MnSO}_{4} \cdot \mathrm{H}_{2} \mathrm{O}$ yield at different temperatures, the optimal temperature was determined to be $25^{\circ} \mathrm{C}$. In addition, the ratio of $\mathrm{H}_{2} \mathrm{SO}_{4}$ was explored through experimental comparative analysis and, combined with factors such as the yield of $\mathrm{MnSO}_{4} \cdot \mathrm{H}_{2} \mathrm{O}$ crystals, the removal rate of $\mathrm{Ca}^{2+}$ and $\mathrm{Mg}^{2+}$, and the process cost, it was finally determined that the optimal volume ratio of $\mathrm{H}_{2} \mathrm{SO}_{4}$ was $30 \%$. The optimal ratio of $\mathrm{H}_{2} \mathrm{O}$ in the recrystallization experiment was $60 \%$, which could effectively reduce the loss of $\mathrm{MnSO}_{4} \cdot \mathrm{H}_{2} \mathrm{O}$ crystals and could better remove $\mathrm{Ca}^{2+}$ and $\mathrm{Mg}^{2+}$. After six cycles, the removal rates of $\mathrm{Ca}^{2+}$ and $\mathrm{Mg}^{2+}$ were $99.68 \%$ and $99.17 \%$, respectively, and the yield of $\mathrm{MnSO}_{4} \cdot \mathrm{H}_{2} \mathrm{O}$ crystals was $80.54 \%$. The product was washed with ethanol, and the best volume ratio of ethanol was $100 \%$. Finally, the product was tested and analyzed by XRD, ICP and AAS, and all the indicators of the sample met the requirements of high-purity $\mathrm{MnSO}_{4} \cdot \mathrm{H}_{2} \mathrm{O}$ crystals. This study not only solved the problems of a low $\mathrm{MnSO}_{4} \cdot \mathrm{H}_{2} \mathrm{O}$ crystals yield and complex processing in the recrystallization process, but also efficiently removed $\mathrm{Ca}^{2+}$ and $\mathrm{Mg}^{2+}$, which could be of great help in practical applications on the industrial-level production of high-purity $\mathrm{MnSO}_{4} \cdot \mathrm{H}_{2} \mathrm{O}$.

Author Contributions: Conceptualization, H.C. and K.W.; methodology, H.C. and Y.W.; software, H.C.; validation, F.Z.; formal analysis, H.C.; investigation, X.M., F.Z., W.L. and H.Z.; resources, K.W. and Y.W.; data curation, H.C.; writing-original draft preparation, H.C. and F.Z.; writing-review and editing, K.W. and Y.M.; visualization, H.C.; supervision, Y.W., W.L. and H.Z.; project administration, K.W. and X.M.; funding acquisition, K.W and F.Z. All authors have read and agreed to the published version of the manuscript. Please turn to the CRediT taxonomy for the term explanation. Authorship must be limited to those who have contributed substantially to the work reported.

Funding: This research was funded by the Science and Technology Major Project of Guangxi Province, grant number: AA18118052. Check carefully that the details given are accurate and use the standard spelling of funding agency names at https:// search.crossref.org/funding. Date of access: 24 August 2021. Any errors may affect your future funding.

Institutional Review Board Statement: Not applicable.

Informed Consent Statement: Not applicable.

Data Availability Statement: Not applicable.

Acknowledgments: This work was financially supported by the Science and Technology Major Project of Guangxi Province (AA18118052). The author is very grateful for the funding of the above institutions, thanks to the support and help of the OLI system in the simulation calculation, and thanks to the CITIC Dameng Mining Industries Limited-Guangxi University Joint Research Institute of manganese resources utilization and advanced materials technology, Guangxi University-CITIC Dameng Mining Industries Limited Joint base of postgraduate cultivation for their assistance in the experiment.

Conflicts of Interest: The authors declare no conflict of interest.

\section{References}

1. Fan, Y.; Makhlouf, M. Stabilizing the strengthening precipitates in aluminum-manganese alloys by the addition of tungsten. Mater. Sci. Eng. A 2017, 691, 1-7. [CrossRef]

2. Zhang, D.; Ma, Z.; Spasova, M.; Yelsukova, A.E.; Lu, S.; Farle, M.; Wiedwald, U.; Gökce, B. Formation Mechanism of LaserSynthesized Iron-Manganese Alloy Nanoparticles, Manganese Oxide Nanosheets and Nanofibers. Part. Part. Syst. Charact. 2017, 34, 1600225. [CrossRef]

3. Tan, L.; Hu, H.; Liao, J.; Wang, C.; Li, C. Preparation of High-purity Manganese Sulfate for Battery by Solvent Extraction. Nonferrous Met. (Extr. Metall.) 2014, 9, 62-65. [CrossRef]

4. Zhang, H.; Zhao, K.; Chen, F.; Jiang, Q. Application Prospect and Development of High Pure Manganese Sulfate Monohydrate in Battery Level. China's Manganese Ind. 2014, 32, 6-8. [CrossRef] 
5. Xie, Y.; Ou, Y.; Hu, B.; Ling, Z. Study on production process for high-purity manganese sulfate with waste sulphuric acid of titanium white-pyrolusite-pyrite. Inorg. Chem. Ind. 2013, 45, 49-51. [CrossRef]

6. Zhao, Y.; Wu, R.; Hu, P.; Jiang, Y.; Jiang, Y. Study on Impurity Characteristics and Purification Process in High Purity Manganese Sulfate. World Nonferrous Metals 2020, 186-188. [CrossRef]

7. Lin, Q.; Liu, Y.; Li, L.; Wang, Y.; Wang, J.; Xu, J.; Si, H.; Peng, B.; Zhu, Z. Study on the process of preparing high-purity manganese sulfate from low-grade manganese carbonate ore. Inorg. Chem. Ind. 2014, 46, 35-38.

8. Wang, Y.; Wang, W.; Liu, Y.; Liu, F.; Chen, X. Removal of Heavy Metals from manganese sulfate solution and preparation of Battery-level manganese sulfate. Nonferrous Metals 2020, 79-84. [CrossRef]

9. Bao, X.; Wang, Z.; Liu, J.; Su, Z.; Tian, S.; Zhou, D.; Wang, H. Experimental study on the removal of calcium, magnesium and iron from the depth of industrial manganese sulfate. Min. Metall. Eng. 2013, 33, 90-93. [CrossRef]

10. Xie, Y.; Ye, Y.; Xie, X.; Nong, Y. Removal of Calcium and Magnesium from Manganese Sulfate by Manganese Fluoride. Technol. Dev. Chem. Ind. 2020, 49, 9-11. [CrossRef]

11. He, T.; Qian, L.; Cui, J.; Shu, H. Deep Removal of Ca and Mg from Industrial Manganese Sulfate with Fluorination Precipitation. Nonferrous Met. (Extr. Metall.) 2018, 5-8. [CrossRef]

12. Ang, H.M.; Reyhani, M.; Tad, M.O.; Safaeefar, P. Growth Kinetics of Manganese Sulphate from Heating and Salting-out Batch Crystallisation. Dev. Chem. Eng. Miner. Process. 2006, 14, 303-312. [CrossRef]

13. Li, X.; Ji, D.; Su, H.; Pan, L.; Li, J.; Li, J.; Wen, Y. Study on production of manganese sulphate by high-temperature crystallizing process. Inorg. Chem. Ind. 2010, 42, 16-19. [CrossRef]

14. Zhao, J.; Wang, W.; Cao, J.; Kou, X. Purification of calcium and magnesium from industrial manganese sulfate liquid by fluoride precipitant. Ind. Water Treat. 2019, 39, 77-81. [CrossRef]

15. Wang, Y.; Zeng, L.; Zhang, G.; Guan, W.; Sun, Z.; Zhang, D.; Qing, J. A novel process on separation of manganese from calcium and magnesium using synergistic solvent extraction system. Hydrometallurgy 2019, 185, 55-60. [CrossRef]

16. Dan, D.; Liu, Z.; Sun, L.; Tang, L.; Zou, X. Removal of Ca and Mg Ions from Industrial Manganese Sulfate Solution by Solvent Extraction. J. Jishou Univ. 2016, 37, 55-62. [CrossRef]

17. Liu, H.; Zhu, G. Study on removal of calcium and magnesium from Leaching solution of manganese ore by solvent extraction. China's Manganese Ind. 2008, 26, 34-37. [CrossRef]

18. Ilea, P.; Popescu, I.C.; Urdă, M.; Oniciu, L. The electrodeposition of manganese from aqueous solutions of $\mathrm{MnSO}_{4}$. IV: Electrowinning by galvanostatic electrolysis. Hydrometallurgy 1997, 46, 149-156. [CrossRef]

19. Farrah, H.E.; Lawrance, G.A.; Wanless, E.J. Solubility of calcium sulfate salts in acidic manganese sulfate solutions from 30 to $105^{\circ} \mathrm{C}$. Hydrometallurgy 2007, 86, 13-21. [CrossRef]

20. He, Y.; Li, F.; Luo, Z.; Luo, K. Preparation of Battery-Grade Manganese Sulfate by Purification of Industrial-Grade Manganese Sulfate with High-Temperature Crystallization Method. Min. Metall. Eng. 2019, 39, 85-88. [CrossRef]

21. Yuan, F.; Feng, Y.; Li, H.; Yi, A.; Li, H.; Wu, M.; Guo, C. Research on Separation of Manganese and Manganese From Manganese Sulfate Solution Containing Magnesium by Evaporation Crystallization. Hydrometall. China 2015, 34, 225-228. [CrossRef]

22. Giulietti, M.; Seckler, M.M.; Derenzo, S.; Ré, M.I.; Cekinski, E. Industrial Crystallization and Precipitation from Solutions: State of the Technique. Braz. J. Chem. Eng. 2001, 18, 423-440. [CrossRef]

23. Zou, X. Present Situation of Production Technology of High Purity Manganese Sulfate. China's Manganese Ind. 2018, 36, 4-6. [CrossRef]

24. Jakovljevic, B.; Bourget, C.; Nucciarone, D. CYANEX (R) 301 binary extractant systems in cobalt/nickel recovery from acidic chloride solutions. Hydrometallurgy 2004, 75, 25-36. [CrossRef]

25. Pakarinen, J.; Paatero, E. Effect of temperature on Mn-Ca selectivity with organophosphorus acid extractants. Hydrometallurgy 2011, 106, 159-164. [CrossRef]

26. Benrath, V.A.; Blankenstein, A. Uber mischkristalle in der vitriolreihe I. Z. Furanorgaische Und All Gem. Chem Emio 1933, 216, 41-47. [CrossRef]

27. Yang, S.; Ren, B.; Wang, C. The Study of Magnesium Removing by Ethanol Recycling for the Technology of Electrolytic Manganese Processing. China's Manganese Ind. 2011, 29, 15-17. [CrossRef]

28. Li, W.; Jia, J.; Zhao, X.; Ji, Y. Simulation and analysis of produced water in Anhui oil production plant with software OLI ANALYZER STUDIO. Comput. Appl. Chem. 2013, 30, 179-182. [CrossRef]

29. Liu, J.; Wu, J.; Feng, J.; Yan, W. A Review of Fabrication and Purification of Manganese Sulphate. China's Manganese Ind. 2017, 35, 114-118. [CrossRef]

30. Yuan, M.; Qiu, G. Study on the removing of $\mathrm{MgSO}_{4}$ from $\mathrm{MnSO}_{4}$ solution based on the aqueous system phase diagram. Cent. South Univ. Technol. 2000, 212-214. [CrossRef]

31. Cottrell, F.G. On the Solubility of Manganous Sulphate. J. Phys. Chem. 2002, 4, 637-656. [CrossRef]

32. Matricardi, L.R.; Downing, J.; Staff, U.B. Manganese and Manganese Alloys. Kirk-Othmer Encycl. Chem. Technol. 2012. [CrossRef]

33. Safaeefar, P.; Ang, H.M.; Kuramochi, H.; Asakuma, Y.; Maeda, K.; Tade, M.O.; Fukui, K. Measurement and correlation of the solubility of $\mathrm{MnSO}_{4} \cdot \mathrm{H}_{2} \mathrm{O}$ in ethanol+water $+\mathrm{MgSO}_{4} \cdot 7 \mathrm{H}_{2} \mathrm{O}$ solutions. Fluid Phase Equilibria 2006, 250, 64-69. [CrossRef] 